second world war. Although a Nazi, he refused to experiment on helpless human guinea pigs, saying this was a price he would never pay for the realisation of his dreams. Those in the UK who seek to change the law to allow experimentation on patients with mental incapacity, without their consent, would do well to follow his example. This is a particularly fraught area of medical ethics, and any such research should only be done if it is likely to be of some benefit to the patient.

Another fascinating chapter is about the development of anaesthetics. An English clergyman, and accomplished chemist, Joseph Priestley, prepared pure oxygen and nitrous oxide back in 1774. Then he inspired Dr Thomas Beddoe to found the Medical Pneumatic Institution, and Humphrey Davy was appointed first director. Davy tried nitrous oxide on himself and discovered its analgesic properties, but doctors ignored his findings for 40 years.

People lived dangerously in the past but the lack of regulation enabled inspired individuals to explore their creativity in freedom. There are many stories of courage and daring in the book, not least that of Dr Frederick Prescott of Burroughs Welcome, who in 1944 consented to be the human guinea pig for curare.

There are nuggets of interest to medical ethicists in the book, but you have to discover them for yourself. It is not primarily a book about medical ethics. Some eloquent quotes come from Dr Stephen Elek, once professor of bacteriology at St George's Hospital, London. He said: "If anything goes wrong and the skid row bum dies, and the experimenter has not done it on himself, he is liable for murder. It's as simple as that. A man is entitled to risk his own life. He is not entitled to risk somebody else's".

In the final chapter, Altman looks at what motivates people to experiment on themselves. He also considers the limitations of self-experimentation. He stresses that the risk of performing an unethical human experiment is enormous. Increased attention to the question of who goes first, he argues, would improve the quality of the informed consent process that the Nuremberg Code has made mandatory.

\title{
Ethics and Values in Health Care Management
}

\section{Edited by Souzy Dracopoulu, Lon- don, Routledge, 1998, 200 pages, $£ 14.99$.}

This book aims to present an "up-todate-analysis of the relationship between ethics and management of the health care services". This includes a debate about the status of ethics in health care management. In addition it offers studies of health care reform related to value criteria in Poland, France and Greece.

Loughlin produces a spirited attack on the view that an ethic for managers can be constructed. His complex case involves two related arguments. First, that this enterprise is inextricably bound up with demands for rationing which treat socially generated scarcity as natural. Second, that the correct standard for ethical reasoning requires a level of deductive proof which is unavailable to those who treat the present structure of liberal democracies as a given. In conducting his attack he examines arguments, published elsewhere, made by contributors to this volume such as Andrew Wall, former health services manager and author of one of the all too rare books on health care management ethics and Alan Williams, defender of the QALY (Quality Adjusted Life Year). None of the contributors discuss one another's arguments as presented here. This is a shame as direct engagement amongst the contributors would have given us sharper definition of the issues. The very important points presented by Loughlin that every would-be manager and every philosopher serving on quangos should have to consider, jostle next to his arguments about social policy formation that do not get the adversarial attention they warrant.

Wall presents an accessible runthrough of ethical issues a senior manager might come up against including: research, purchasing decisions and termination of active treatment. $\mathrm{He}$ notes that managers are not bound by professional discipline, that "anyone can become a health services manager" and that ethics is not synonymous with law. Since Wall has argued that managers should treat patients as bearers of rights and has acted on this in practice, his statement of principles should not be dismissed by Loughlin as so general that "no-one in their right mind could disagree with them: Utilitarians disagree with Wall at the conceptual level, and local campaigi ers committed to maintaining the value of their property can make 1 ese difficult for a manager committed $\$$ implementing service plans designed to protect "rights" of people with mental health problems.

Loughlin asserts that role definitions lock managers into organisationg imperatives which cannot accomm date need. In contrast, Chadwi insists that there are ethical ambigivio ties endemic to deliberate decision making in any complex society which are distinct from questions abof rationing. She shifts discussion from managers to the management function, starting with National Health Service (NHS) goals which give specta weight to justice, efficiency and accep ability to users. An approach co cerned to maximise the health of the community rather than one to promoses the flourishing of individuals appears to fit with these goals. But she noteg that the provision of information, as the case of genetics services, is requirement, understandable within virtue ethics approach, explicitly eक्षे chewing population health outcomes.

The three European case studie supply ample evidence of pervasice non-rational social factors whic shape attempts to improve regulation of their health care systems. They tre the strengthening of the manageme function as essential to giving weigf to ethical concerns. The Europea contributors, along with Loughlip, present a challenge: are managers equipped with the broad, multidisci plinary knowledge base, including humanities and social sciences, enable them to make their way respon. sibly through these issues?

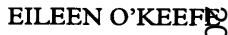

School of Health Studies University of North Londow

Informed Consent in Psychiatry: European Perspectives of Ethics Law and Clinical Practice

Edited by $\mathrm{H}$ Koch, S Reiter-Theil and $\mathrm{H}$ Helmchen, Baden-Baden, Nomos Verlagagesellschaft, 1996, 42 pages, 88DM. 